\title{
Use of C-reactive protein level in diagnosis of tubercular pleural effusion
}

\author{
Pant S', Shrestha SK², Sharma L', Shrestha B ${ }^{3}$
}

'Subash Pant, Lecturer; ${ }^{2}$ Sanjeet Krishna Shrestha, Assistant Professor; ' $L u c k y$ Sharma, Lecturer; ${ }^{3}$ Bibechana Shrestha, Medical Officer; Department of Internal Medicine, Kathmandu Medical College Teaching Hospital, Kathmandu, Nepal.

\begin{abstract}
Background: C-reactive protein in both pleural fluid and serum has been found to be higher in tubercular pleural effusion than in other causes of pleural effusion.

Objectives: The main aim of this study was to find out the diagnostic value of C-reactive protein in patients with lymphocytic pleural effusion.

Methodology: A cross-sectional study was conducted in 90 patients with pleural effusion who underwent thoracocentesis at Kathmandu Medical College Teaching Hospital, Kathmandu, Nepal. The complete biochemical tests of pleural fluid and serum were performed. The C-reactive protein concentrations of both pleural fluid and serum were then measured from samples from patients with lymphocytic exudative pleural effusion.

Results: Ninety patients with exudative lymphocytic pleural effusion were included. Male patients were 56 (62.2\%) and female were $34(37.8 \%)$ with the male to female ratio of 1.64. Mean age of the patients was $51 \pm 21.54$ (Mean \pm Standard Deviation). The pleural fluid C-reactive protein levels in tubercular pleural effusion were higher $(48.87 \pm 24.19 \mathrm{mg} / \mathrm{dl})$ compared to non-tubercular group $(38.30 \pm 17 \mathrm{mg} / \mathrm{dl} ; \mathrm{p}<0.001)$. Similarly, the serum fluid C-reactive protein levels in tubercular pleural effusion were higher $(29.60 \pm 13 \mathrm{mg} / \mathrm{dl})$ compared to non-tubercular group $(18.14 \pm 9.2 \mathrm{mg} / \mathrm{dl} ; \mathrm{p}<0.001)$. The sensitivity of pleural fluid C-reactive protein level in diagnosing tubercular pleural effusion was $86 \%$.

Conclusion: Simple and inexpensive test like C-reactive protein is useful in the diagnostic workup of lymphocytic pleural effusions. High C-reactive protein levels are very suggestive of tubercular pleural effusion.
\end{abstract}

Key words: Adenosine deaminase; C - reactive protein; Tubercular pleural effusion.

DOI: https://doi.org/10.3126/jkmc.v8i1.25264

\section{INTRODUCTION}

T ubercular pleural effusion is the second most common cause of extra-pulmonary tuberculosis ${ }^{1}$. Pleural effusion is an abnormal collection of fluid in the pleural cavity, a potential space between visceral and parietal pleura, thus restricting the normal movement of the lungs. The rate of accumulation of fluid exceeds the rate of absorption with production of pleural effusion ${ }^{2}$. Tuberculosis remains one of the important causes of exudative pleural effusion especially in a country like Nepal. Beside tuberculosis, malignancy and parapneumonic effusion are the two other important

Address for correspondence

Dr. Subash Pant

Lecturer, Department of Internal Medicine

Kathmandu Medical College Teaching Hospital

Kathmandu, Nepal.

E-mail: subashpant26@gmail.com causes of exudative pleural effusion. Tubercular pleuritis usually presents as an acute illness. Tubercular pleural effusion (TPE) is more common in men, with an overall male-to-female ratio of $2: 1^{3}$. The most common symptoms of TPE are non-productive cough and pleuritic chest pain; if both cough and chest pain are present, the pain usually precedes the cough ${ }^{4-6}$. Fever is present in a majority of cases but approximately $15 \%$ are found to be afebrile.TPE patients, with a large effusion present with dyspnoea. Other symptoms include malaise, night sweats and weight loss ${ }^{1}$.

The definitive diagnosis of TPE depends on the demonstration of Mycobacterium tuberculosis in the sputum, pleural fluid, or pleural biopsy specimens $s^{1,7}$. The presumptive diagnosis can also be established with reasonable certainty by demonstrating granuloma in the parietal pleura or elevated concentrations of adenosine deaminase (ADA) or interferon-in pleural 
fluid in clinically suspected cases ${ }^{1,8}$. Moreover, facilities of pleural biopsy may not be available in all the medical centres and if available, there are very few laboratories where the histopathological reporting are performed. Therefore a rapid, simple, inexpensive and reliable test for diagnosis of TPE is required.

Different biomarkers like $A D A$ and C-reactive protein (CRP) have been used to diagnose TPE. In this study, we mainly focused on these two biomarkers. Adenosine deaminase (ADA) is an enzyme, closely related to $T$ lymphocyte activity and is produced by almost every cellofthe human body but its levels are higher in lymphocytes. ADA plays an importantrole in the differentiation and maturation of the lymphoid system.

CRP is an acute phase reactant protein that is produced by the liver and is present in the body before the antibodies ${ }^{10}$. CRP has an important role in the immune system: it has the ability to recognize the organism and to eliminate them through the recruitment of the phagocytotic cells and the complement system in both serum and body fluids. Unfortunately, the ADA test is not available in all medical centers in Nepal, where incidence of tuberculosis is very high. For this reason, alternative test like CRP with lower cost and greater availability are of great interest. The main aim of this study was to find out whether CRP titer may aid in diagnosing the lymphocytic tubercular pleural effusion in conjunction with ADA.

\section{METHODOLOGY}

The study was conducted at Kathmandu Medical College Teaching Hospital from December 2016 to May 2018. This was a cross sectional study performed in 90 clinically suspected patients of tubercular pleural effusion. All suspected patients of tubercular pleural effusion were subjected to detailed history taking, clinical examination, chest $\mathrm{x}$-ray and thoracic ultrasound, tuberculin test and aspiration of pleural fluid. Venous blood samples and pleural fluid were collected under aseptic conditions, simultaneously, and all patients underwent serum and pleural fluid measurements within 24 hours.

The pleural fluid was sent for biochemical examination including: Protein, Lactate Dehydrogenase (LDH), Adenosine Deaminase (ADA), CRP levels, cytological examination and bacteriologic examination. Venous blood samples were sent for ESR, Protein, LDH and CRP titer. Classification of pleural fluid into transudative or exudative is based upon Light's criteria'. Only lymphocytic exudative pleural effusion cases were enrolled in the study. The other group were termed as non-tubercular group who had exudativeneutrophilic pleural effusion .The diagnosis of tubercular pleurisy was based upon occurrence of lymphocytic pleural fluid and elevated ADA level $(\geq 50 \mathrm{IU} / \mathrm{L})$ in pleural fluid ${ }^{11}$. Pleural fluid CRP level of $\geq 50 \mathrm{mg} / \mathrm{dl}$ is taken as positive for diagnosis of tubercular pleural effusion ${ }^{12}$.

Data was recorded in a pre-designed proforma and entered into IBM-Statistical Package for the Social Sciences (SPSS) version 20 and evaluated. Baseline characteristics of patients were evaluated using descriptive statistics. Categorical variables were expressed in numbers and percentage (\%). Quantitative variables were expressed in mean $\pm S D$. The performances of diagnostic test were expressed in terms of sensitivity and specificity. Statistical significance was set with p-value $<0.05$ with Confidence Interval of $95 \%$. ChiSquare test was used for categorical variables. Sensitivity and specificity of the test were also calculated.

\section{RESULTS}

There were total 90 patients enrolled in the study. Male patients were $56(62.2 \%)$ and female were $34(37.8 \%)$ of total, with the male to female ratio of 1.64. Mean age of the patient was $51 \pm 21.54$ years. The most common complaint of the patients was shortness of breath. It was present in more than $50 \%$ of the cases. Fever was present only in $17(18.9 \%)$ of the cases (Table 1).

Among 90 cases, smoking history was present in 31 (34.4\%). When we look at smoking and pleural fluid tuberculosis, there was no significant correlation $(p=0.84)$ observed. Patients with type 2 diabetes mellitus were only 5 (5.6\%). Past history of some form of tuberculosis were present in $6(6.7 \%)$ cases.

Appetite was decreased in 22 (24.4\%) of the total cases. Despite loss of appetite being the major concern in most of the tuberculosis patients, the correlation of appetite and tubercular pleural effusion was not significant in this study ( $p=0.138$ ). The mean ADA in tubercular pleural effusion was $81 \pm 11 \mathrm{IU} / \mathrm{L}$ and non-tubercular pleural effusion was $35 \pm 11 \mathrm{IU} / \mathrm{L}$ (Table 2). Total 13 (14.4\%) cases underwent chest tube insertion and drainage. There were total $7(7.8 \%)$ cases where pleural effusion was loculated. On doing the Mantoux test and sputum AFB, there were no significant correlation $(p=0.66$ and $p=0.62$ respectively) with occurrence of pleural tuberculosis.

The pleural fluid CRP levels in tubercular pleural effusion were higher $(48.87 \pm 24.19 \mathrm{mg} / \mathrm{dl})$ compared to nontubercular group $(38.30 \pm 17 \mathrm{mg} / \mathrm{dl} ; \mathrm{p}<0.001)$. Similarly, the serum CRP levels in tubercular pleural effusion were 
higher $(29.60 \pm 13 \mathrm{mg} / \mathrm{dl})$ compared to non-tubercular group (18.14 $\pm 9.2 \mathrm{mg} / \mathrm{dl} ; \mathrm{p}<0.001)$ (Table 4). The pleural fluid to serum CRP ratio were almost similar in tubercular $(1.79 \pm 1.06)$ and non-tubercular (1.86 \pm 1.05$)$ group. The sensitivity of pleural fluid CRP level in diagnosing tubercular pleural effusion is $86 \%$, whereas the specificity was quite low of $37 \%$. The sensitivity of serum CRP titer level in diagnosing tubercular pleural effusion was 65\%, whereas compared to pleural fluid, the specificity of serum CRP titer was quite high of $88 \%$.

\section{DISCUSSION}

One can easily diagnose the case of pleural effusion but its difficult to give the etiological cause of pleural effusion, therefore the diagnosis of aetiology of pleural effusion is a difficult in spite of being the easier task to establish pleural effusion. Various cellular, microbiological and biochemical analyses alone cannot be enough to diagnose a case of pleural effusion. The present study provides evidence of the use of pleural fluid CRP measurement in diagnosing the tubercular pleural effusion. In most cases, CRP tends to be more accurate in reflecting the ongoing inflammation and tissue damage.
Our results revealed that the mean value of pleural fluid CRP ( $p-C R P)(46 \pm 27.9)$ as well as serum CRP (s-CRP) $(26 \pm 13.58)$ were higher in tubercular pleural effusion compared to non-tubercular pleural effusion with statistical significance $(p<0.001)$. Chierakul et $\mathrm{al}^{13}$ in their study of 161 cases of pleural effusion, found that $p$-CRP and s-CRP levels were significantly higher in tubercular pleural effusion compared to non-tubercular cases. Similar results were also observed in a study by GarciaPachon et $\mathrm{al}^{12}$. The author concluded that high CRP levels are very suggestive of tubercular pleural effusion and low CRP levels make the diagnosis unlikely.

In the current study, we use the cut-off value of CRP of $\geq 50 \mathrm{mg} / \mathrm{dl}$. The sensitivity of pleural fluid in diagnosing tubercular pleural effusion is $86 \%$, whereas the specificity was quite low of $37 \%$. The sensitivity of serum CRP titer level in diagnosing tubercular pleural effusion was 65\%, whereas compared to pleural fluid, the specificity of serum CRP titer was quite high of $88 \%$. These findings were similar to study done by Park et al and Botana-Rial et $\mathrm{al}^{14,15}$.

In our study, the pleural fluid to serum CRP ratio was almost similar in tubercular $(1.79 \pm 1.06)$ and non-

Table 1: Chief complaint of the patient of pleural effusion $(n=90)$

\begin{tabular}{lcc}
\hline Chief complaint of the patient & Frequency $(\mathbf{n})$ & Percentage (\%) \\
\hline Shortness of breath & 50 & 55.6 \\
\hline Fever & 17 & 18.9 \\
\hline Cough & 13 & 14.4 \\
Chest Pain & 10 & 11.1 \\
\hline
\end{tabular}

Table 2: Pleural fluid parameters in Tubercular and non-tubercular pleural effusion

\begin{tabular}{|lcccccc} 
Parameters & $\begin{array}{c}\text { Total Count } \\
\text { (cells/mm3 of blood) }\end{array}$ & $\begin{array}{c}\text { Protein } \\
\text { (gm/dl) }\end{array}$ & $\begin{array}{c}\text { Sugar }(\mathbf{m g} / \\
\mathbf{d l})\end{array}$ & $\begin{array}{c}\text { Lactate Dehydrogenase } \\
\text { (LDH) } \mathbf{m g} / \mathbf{d l}\end{array}$ & $\begin{array}{c}\text { CRP titer } \\
\text { Pleural Fluid } \\
\text { ADA (IU/L) }\end{array}$ \\
\hline Tubercular & $1460 \pm 162$ & $3.8 \pm 0.97$ & $95 \pm 26$ & $482 \pm 89$ & $48 \pm 24$ & $81 \pm 11$ \\
Non-tubercular & $978 \pm 618$ & $5.2 \pm 1.5$ & $105 \pm 33$ & $258 \pm 108$ & $38 \pm 37$ & $35 \pm 11$ \\
\hline
\end{tabular}

Table 3: Serum parameters in Tubercular and non-tubercular pleural effusion

\begin{tabular}{lcccc} 
Parameters & $\begin{array}{c}\text { Erythrocyte Sedimentation } \\
\text { Rate (ESR) } \mathbf{~ m m / h r}\end{array}$ & Protein (gm/dl) & $\begin{array}{c}\text { Lactate Dehydrogenase } \\
\text { (LDH) } \mathbf{~ m g / d l ~}\end{array}$ & CRP titer \\
\hline Tubercular & $42 \pm 10$ & $6.4 \pm 0.76$ & $247 \pm 66$ & $29 \pm 13$ \\
Non-tubercular & $18 \pm 9$ & $6 \pm 1.0$ & $249 \pm 99$ & $18 \pm 9$ \\
\hline
\end{tabular}

Table 4: CRP levels in various body fluids in tubercular and non-tubercular groups

\begin{tabular}{lcc} 
Body Fluids & $\begin{array}{c}\text { CRP levels in Tubercular Pleural Effusion } \\
\text { (Mean } \pm \text { SD) }\end{array}$ & $\begin{array}{c}\text { CRP levels in Non-tubercular Pleural Effusion } \\
\text { (Mean } \pm \text { SD) }\end{array}$ \\
\hline Pleural fluid & $48.87 \pm 24.19$ & $38.30 \pm 17$ \\
Serum & $29.60 \pm 13$ & $18.14 \pm 9.2$ \\
\hline
\end{tabular}


tubercular groups $(1.86 \pm 1.05)$. This finding was quite contrasting to various studies. In a study done in Turkey on use of pleural fluid CRP titer in diagnosing various aetiologies, the pleural fluid to serum CRP ratio was 2.9 \pm 1.1 compared to malignant pleural effusion (1.1 \pm 0.2$)$. In their study, the ratio of pleural fluid to serum CRP was also significantly higher in the exudative effusion group than in the transudative effusion group ( $p<0.003)$. In addition, this ratio was significantly lower in the neoplastic effusion sub-group than in the parapneumonic effusion sub-group $(p<0.0002)^{16}$.

This study shows the importance of CRP in the diagnostic yield in pleural effusion. Our results revealed that the mean value of pleural fluid CRP ( $p$-CRP) $(46 \pm 27.9)$ as well as serum CRP (s-CRP) $(26 \pm 13.58)$ were higher in tubercular pleural effusion compared to non-tubercular pleural effusion with statistical significance $(p<0.001)$.

\section{REFERENCES}

1. Light RW. Pleural diseases. 6th ed. Philadelphia: Lippincott Williams \& Wilkins, 2013.

2. Light RW. Clinical practice. Pleural effusion. New England J Med[Internet]. 2002 Jun 20 [cited 2018 Jan 2]; 346 (25):1971-7.[PubMed]

3. Porcel JM. Tuberculous pleural effusion. Lung [Internet] 2009 Sept-Oct [cited 2017 Mar 08]; 187 (5):263-70.[PubMed]

4. Berger HW, Mejia E. Tuberculous pleurisy. Chest [Internet] 1973Jan [cited 2017 Sept 09]; 63:88-92. Available from: [DOI]

5. Seibert AF, Haynes J, Jr, Middleton R, et al. Tuberculous pleural effusion. Twenty-year experience.Chest [Internet].1991 [cited 2017 Jun 6];99:883-6. [DOI]

6. Wang $\mathrm{Z}, \mathrm{Xu} \mathrm{LL}, \mathrm{Wu} \mathrm{YB}$, et al. Diagnostic value and safety of medical thoracoscopy in tuberculous pleural effusion. Respir Med[Internet] 2015[cited 2017 July 9]; 109:1188-92. [PubMed]

7. Diagnosis and treatment of tuberculous pleural effusion in 2006.Gopi A, Madhavan SM, Sharma SK, Sahn SAChest [Internet]. 2007 Mar [cited 2017 Oct 2]; 131(3):880-889. [PubMed]

8. Novel tests for diagnosing tuberculous pleural effusion: what works and what does not? Trajman A, Pai M, Dheda K, van ZylSmit R, Zwerling AA, Joshi R, Kalantri S, Daley P, Menzies D. EurRespir J[Internet]. 2008 May [Cited 2017 Feb 23]; 31(5):1098-106. [PubMed]

9. Genetic home reference. Accessed on 16 February, 2016.[Link].

10. Ballou SP, Kushner I. C-reactive protein and the acute phase response. Adv Intern Med[Internet]. 1992
CRP is a simple, rapid and inexpensive test particularly in developing country like Nepal.

The current study had a few limitations. The diagnosis of tubercular pleural effusion was made only by pleural fluid ADA rather than pleural biopsy. Though the diagnostic yield of pleural fluid ADA is quite high, the definitive and the diagnostic method is always pleural biopsy.

\section{CONCLUSION}

The value of a simple, cheaper and feasible test is always a great asset for reaching a diagnosis of any case. This study shows that CRP titer may not be the diagnostic tests for tubercular pleural effusion but it will definitely help in coming to conclusion of a diagnosis when performed in conjunction with pleural fluid ADA.

[cited 2017 Apr 22]; 37:313-36: [PubMed]

11. Burgess LJ, Maritz FJ, Le Roux I, et al. Combined use of pleural adenosine deaminase with lymphocyte/ neutrophil ratio. Increased specificity for the diagnosis of tuberculouspleuritis. Chest[Internet].1996[cited 2017 Apr 24]; 109(2):414-9.[PubMed]

12. Garcia-Pachon E, Soler MJ, Padilla-Navas I, Romero V, Shum C. C-reactive protein in lymphocytic pleural effusions: a diagnostic aid in tuberculouspleuritis. Respiration[Internet]. 2005[cited 2018 Jan 6]SepOct;72(5):486-9. [PubMed]

13. Chierakul N, Kanitsap A, Chaiprasert A, Viriyataveekul R. A simple C-reactive protein measurement for the differentiation between tuberculous and malignant pleural effusion. Respirology[Internet]. 2004[cited 2017 Dec 18]; 9(1):66-69. [PubMed]

14. Park DS, Kim D, Hwang KE, Hwang YR, Park C, Seol $\mathrm{CH}$ et al. Diagnostic value and prognostic significance of pleural C-reactive protein in lung cancer patients with malignant pleural effusions. Yonsei Med J[Internet]. 2013 Mar 1[cited 2017 Dec 18]; 54(2):396402. [PubMed]

15. Botana-Rial M, Casado-Rey $P$, Leiro-Fernández V, Andrade-Olivié M, Represas-Represas C, FernándezVillar A. Validity of procalcitonin and C-reactive protein measurement when differentiating between benign and malignant pleural effusion. Clin Lab[Internet].2011[cited 2017 Nov 18]; 57(5-6):373378.[PubMed]

16. U. Yilmaz Turay, Z. Yildirim, Y. Tuekoz, C. Biber, Y. Erdogan, A. I. Keyf, F. Ugurman, A. Ayaz, P.Ergun, Y. Harputluoglu. Use of pleural fluid C-reactive protein in diagnosis of pleural effusions. RESPIRATORY MEDICINE[Internet].2000 May [cited 2017 May 18] 94(5):432-5. [PubMed] 